\title{
The role of strategic leadership in increasing ethical practices among pharmaceutical organiza- tions in Jordan
}

\section{Khalid Thaher Amayreh ${ }^{a^{*}}$}

\section{${ }^{a}$ Business Administration department, Irbid National University, Jordan}

\section{CH R O N I C L E}

\section{Article history:}

Received: December 28, 2019

Received in revised format:

January 302020

Accepted: February 26, 2020

Available online:

February 26, 2020

Keywords:

Strategic leadership

Strategic vision

Ethics in business

\section{A B S T R A C T}

This paper aims at examining the influence of strategic leadership on increasing ethical practices within pharmaceutical organizations in Jordan. Variables of strategic leadership include work environment, leader's traits, leadership style and strategic leaders' performance. The study designs a questionnaire and distributes it among (277) employees and leaders within pharmaceutical organizations in Jordan. The results of the study indicate positive influence of strategic leadership on ethical practices among individuals and employees in the organization. Results also indicate that leadership performance maintained the strongest effect on ethical stands attributed from strategic leadership which gives an indication that a good performance strategic leadership is probably more influential on ethical practices and decision making in pharmaceutical organizations. The study recommends that organizations within pharmaceutical industry should pay extra attention to aspects that are related to increase employees' awareness towards ethics in leadership and business.

C 2020 by the authors; licensee Growing Science, Canada

\section{Introduction}

Ethical leadership appeared as a result of business ethics which came into use in USA through early 70s. By the time of mid 80s the idea of ethics in business was formulated and both academic and business environment started to draw its features based on its uses, benefits and fields of interest (Trevino \& Brown, 2004). Ferrell and Fraedrich (2015) noted that at the heart of the global crisis that has plagued humanity today; there is a lack of ethical leadership in all sectors of human society. This loss of ethical leadership is clearly demonstrated by the constant detection of unethical behavior at all levels of society around the world. No area of human endeavor, from the family to the highest degree of power, remains unaffected. It is often difficult to distinguish moral leadership because society presents many contradictory statements about the meaning of leadership. Participants at the symposium found that it may be useful to identify some of the key capacities that characterize effective ethical leadership and initiate an organized learning process that encourages the development of these capacities within institutions that serve the human community (Palazzo \& Richter, 2005). Our first challenge is to clearly define what is meant by "leadership". The word leader often comes to mind in contrast to the way it was used in this discussion. When people are asked to define a "leader", they often say, "The person in charge, who orders and has control of things". Unfortunately, the pages of history are full of those who defined leadership in this way.

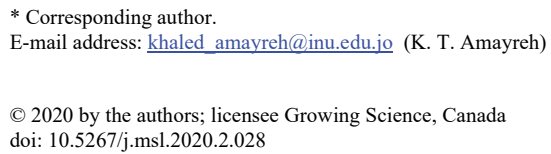




\section{Theoretical Gap}

The forms of leadership, 'autocratic', 'paternalistic', 'manipulative', and leadership that they know of all things 'know-it-all', tend to weaken since those who are supposed to be based on their service, exercise control by making the decision-making process purely centralized, thereby forcing others to bow (Mihelic et al., 2010). On the same track, there appeared the idea of strategic leadership which can be seen as an approach to regenerate and handle many gaps within the organization specifically in case there was a malfunction within ethical stream in organization. On that idea, Rhaima (2012) stated that strategic leadership has the ability - along with its dimensions - to regenerate work environment through handling work pressure and pave the way to leaders in order to handle work pressure and maintain the suitable level of ethics within environment. Also, Tutar et al. (2011) insisted on the fact that strategic leadership and ethical leadership are two main concepts that cannot be separated due to their intersected reality. Also, Rutherford et al. (2012) found a relationship between strategic leadership and ethical leadership that is attributed to both concepts influence on individuals. Authors argued that a strategic leader is more likely to have an influence on their employees which makes easier for them to apply positive change that is attributed to their positive traits and controlling leadership. Gichuhi (2017) saw that ethics is an important factor in an organization which was seen to be a driver to growth of business and development of performance, from that point, ethics in business environment should be managed and dealt with through the focus of not only management but also leadership. According to what was mentioned before, and based on the presented argument; current study focused on examining the influence of strategic leadership variables (work environment, leader's traits, leadership style, strategic leaders' performance) on increasing ethical practices within pharmaceutical organizations in Jordan. The following model highlights the relationship formulated from aim of study.

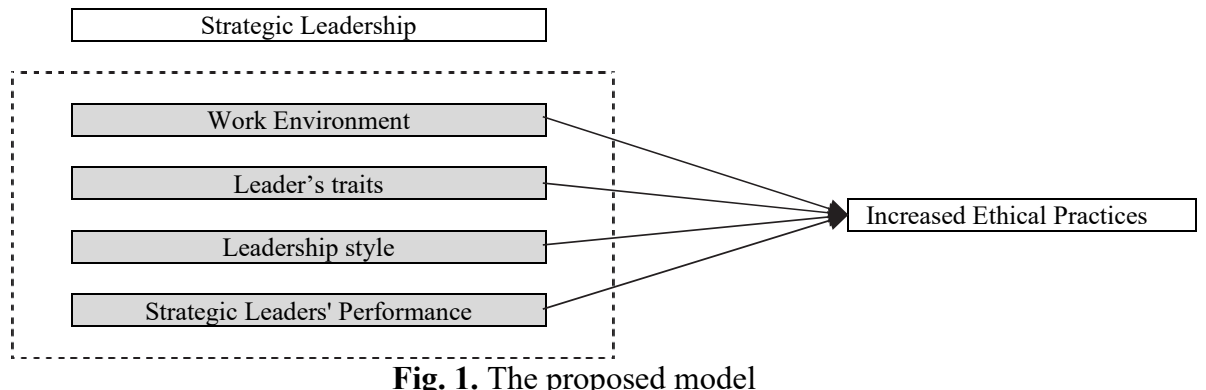

From the model presented in Fig. 1, the following hypotheses are formulated:

\section{Main hypotheses:}

H: Strategic leadership has an influence on ethical practices within an organization.

\section{Sub-Hypothesis:}

$\mathbf{H}_{1}$ : Work Environment has an influence on ethical practices within an organization.

$\mathbf{H}_{2}$ : Leader's Traits has an influence on ethical practices within an organization.

$\mathbf{H}_{3}$ : Leadership Style has an influence on ethical practices within an organization.

H4: Strategic Leaders' Performance has an influence on ethical practices within an organization.

\section{Scholarly Literature}

\subsection{Leadership Definition}

According to Davies and Davies (2004: 30) leadership was defined as "a process of influence leading to the achievement of desired purposes. It involves inspiring and supporting others towards the achievement of a vision which is based on clear personal and professional values", as for strategic leadership Davies and Davies (2004: 32) defined it as "a form of leadership that is concerned with the 'development of the organization as a whole which includes its changing aims and capabilities".

According to Chanpoom and Intrawong (2019) leadership refers to the ability to understand the key elements of creative strategic thinking, to understand the steps of the creative planning process and its implementation, as well as to understand and write down the strategic plan, while Van Schalkwyk et al. (2010) noted that leadership plays an influential role in the process of implementing the strategy through many leadership practices or actions. Leadership is based on strategic analysis and planning based on the logic of strategic thinking. It is characterized by a clear vision of the future based on the orientation of the future. To place the organization at the forefront, it is more extensive than traditional leadership, which focuses on operational plans in the face of real-time events only, and tends to adhere to follow the work instructions and procedures (Davies \& Davies, 2004). 


\subsection{Strategic Leadership}

Strategic leadership refers to the ability to understand the key elements of creative strategic thinking, to understand the steps of the creative planning process and its implementation, as well as to understand and write down the strategic plan (Carter \& Greer, 2013). While Avolio (2007) saw that strategic leadership is an ongoing process, and those who reach this position must first decide how to proceed in this ongoing process. A leader who focuses on the human side of strategic leadership that his company strategy grows stronger as the depth and breadth of understanding and commitment it achieves. This type of leader is able to guide and respond to matters ex officio while promoting commitment and encouraging the empowerment of employees at all levels (Kanungo, 2001). Gallagher and Tschudin(2010) saw that strategic leadership outlines the vision and directions for the organization's growth and success.

Strategic leaders can be found at the head of large corporations in general, where the foundation of their work is to establish an organizational structure and seek to attract investors, sources of funding and other resources. This is achieved by drawing the organization's strategic vision and passing it on to employees and investors alike (Wu et al., 2015).Myers and Pierce (2009) stated that these leaders are well aware of the importance of striking a delicate balance between the strength of the institutional system and the power of human resources, so they rely on strong second-class leaders, giving them enough space to focus and deal with the most important issues that affect the company. According to Bouhali et al. (2015), there are specific actions which leaders have to adopt in order to be considered as strategic leaders among these actions:

- Identify, from their top positions, the course of events and closely monitor the implementation process, as well as diagnose obstacles to the effective implementation of the strategy through the development of an extensive formal and informal information network in the organization.

- Establishing an organizational culture that motivates individuals in the organization to implement the strategy according to the highest acceptable levels of implementation (cultural change).

- Work to keep the organization in a state of response to changing circumstances (flexibility) through the early diagnosis of new opportunities and generate new ideas.

\subsubsection{Strategic Leadership Dimensions}

\section{Work environment}

All managerial literature confirmed the importance and high influence of work environment in driving and motivating organization into either good high performance or low performance. The idea of work environment is an aspect in the organization that is highly influential on all individuals of an organization including employees, management and leaders. When looking at management from a critical eye it can be seen that leaders play a role in defining and framing organizational work environment and determine its influence on employees and their performance. Myers and Pierce (2009) argued that leaders have the ability to present better work environment through focusing on adopting ethics and positive morals which in its turn can help in building an atmosphere for employees that is positive and supportive to ethics. Grant (2012) on the other hand stated that if leaders had the ability to build a good work environment for employees, they would be more attracted towards adopting ethics and work on them through their job in order to present outcomes that are based on ethics and excellence.

\section{Leader's traits}

Being a leader is no picnic as according to Takeuchi et al. (2009). Authors argued that being a leader is the state where a person has to have all what it takes to be able to influence individuals and make them believe deeply and profoundly that this leader wants the best for them. For that sake, it can't be a joke to be a leader and not have the needed traits of a leader. As for a strategic leader, there are many traits that enable an individual to be strategic in their leading process along with the aspect of being ethical in the leading process. Jansen et al. (2009) assured that the leaders' traits are important in defining how strategic they are in terms of their ability to influence others and support them during their journey of achieving goals, mission and see the vision of their organization.

\section{Leadership style}

There are many styles of strategic leadership given that leadership in general isn't an aspects that can be applied, it is more of a stream of thinking in the process of leading but it has lots of styles among them positive and negative leaders or bosses, autocratic or authoritarian leadership, democratic or participative leadership, laissez-faire or free-rein leadership and paternalistic leadership (McCleskey, 2014). However, it can be seen that there are many styles of leadership that digest strategic approach in accepting leadership and may have an influence on the ethical practices within an organization (Auvinen et al., 2014).

\section{Strategic leaders' performance}

Performance is a key issue here. When a leadership is following ethical standards and it is showing a development in performance it is more probably that it will pass the culture to other individuals believing in the positive influence of ethics on their own performance. It is always known that better performance can draw the attention of other individuals towards understanding the motives behind such good performance like higher management and managers. From that point the relationship might be clearer and more indicating towards connecting between good performance of leadership and ethical values may attract individuals towards adopting hose ethics in their own work (Graham et al., 2015). 
Characteristics of strategic leaders may vary according to organizational field of interest and nature of activities they perform. However, Phipps and Burbach (2010) noted that there are common specifications that are found within strategic leaders which can include personal traits based on high communicative skills, motive, their ability to differentiate between individuals' abilities and skills, and cognitive abilities that make them more acceptable socially. On the other hand, Dyson (2014) noted that among the specifications of strategic leaders is their social intelligence and behavioral complexity which makes them more able to influence others and insert in individuals' positive traits and feelings. Phipps (2012) stated that the ability to treat different individuals with different personalities is one of strategic leaders' traits as a leader has to convey with others' mental status, personality differences, nature and motives.

\section{Ethical Leadership}

Sometimes, a leader is offered many administrative cases that require decisions to be addressed. Among these cases, regulations and instructions can be applied to them because of the provisions governing the situation presented. There are cases that require decisions, but the administrative leader does not find in law and order and instructions can be based on (Petryna et al., 2006). The administrative leader may find conflicting instructions or regulations or obsolescence in the texts that make the possibility of benefiting from the legal authority is not possible, and then the administrative leader is forced to diligence and takes the appropriate decision. Here the role of ethical leadership in which the strategic leader believes in guiding his decision and determining his choice among the alternatives available to solve the problem or to decide the administrative situation presented. Ethics is the science of trial and error or the science of good and evil and is a well-established characteristic of the self makes good acts issued by them without cost. When a leader strives for his opinion on any matter, he/she rules his values; ethics and beliefs so that what he/she issues is consistent with what he believes are true (Santoro \& Gorrie, 2005).

In pharmaceutical industry ethics is a subject that requires a significant amount of work from the government and independent consumer protection to protect the economy and the consumer from corporate greed, mismanagement and monopoly. The damage to the economy is in terms of quality, fair competition, justified prices and market economy, for example when a large company tries to compete on the basis of a low price that may be less than the cost or the same cost to go bankrupt companies that cannot compete on that basis. The damage to the consumer is when these companies subsequently deplete their savings when fewer competitors, fewer options and quality, and prices rise, because of monopoly (Rogers et al., 2004). Ethics of profession is not limited to a specific sector, but includes industrial, commercial and service sectors related to the health and safety of the consumer such as food industry, pharmaceutical industry and the electrical appliances industry. Not surprisingly, the focus of distinguished companies on the importance of ethics of the profession after the discovery of the consumer many products containing health risks that may lead to the death of the consumer (Petryna et al., 2006).

\section{Materials and Methods}

Quantitative approach was used on current study in order to gather needed data. Population of study consisted of (108) pharmaceutical organizations in Jordan, (84) organizations were chosen and (5) leaders were extracted as a sample of study forming (420) individuals as according to Www.Surveysystem.com. After the application process, researchers were able to retrieve (277) properly filled questionnaires which made the response rate of $(65.9 \%)$ as statistically accepted. A reliability test was carried out using Cronbach's alpha, the result showed a value of (0.936) for the all items as well as alpha for each variable is greater than accepted percent 0.60 , which is a reasonable value indicating the tool consistency that enhanced its use for the study. Data gathered from questionnaire was processed and screened depending on SPSS.

\subsection{Personal characteristics of the participants}

The demographic results of study respondents are measured in terms of gender, age, education and job experience. It is found that males formed majority of respondents forming (61.7\%) of total sample, while females formed (38.3\%) of total sample with frequency of 106 individuals. It is found that majority of sample formed $(34.3 \%)$ of the sample with the age range of (22-27 years) followed by individuals who were within the age range of (28-33) forming (28.9\%) of total sample. It is found that that majority of sample formed (75.5\%) of total sample who held the degree of (BA) compared to least degree held by respondents which appeared to form $(2.5 \%)$ of the sample who held $\mathrm{PhD}$ degree. It is found that majority of sample had an experience of (5-7 years) forming (47.3\%) of total sample, compared to individuals who had an experience of +11 years forming $6.1 \%$ of total sample.

According to Table 1, it can be noticed that participants had a positive attitude towards statements of questionnaire in addition to study variable considering that mean of answers scored higher than mean of scale 3.00 . 
Table 1

Questionniare analysis

\begin{tabular}{|c|c|c|c|c|c|}
\hline \multirow{2}{*}{\multicolumn{6}{|c|}{ Strategic leadership }} \\
\hline & & & & & \\
\hline \multicolumn{6}{|l|}{ Work Environment } \\
\hline Strategic leadership is supported by a well-built environment & 277 & 1 & 5 & 4.26 & 1.013 \\
\hline Work environment in essential in developing a strategic leader & 277 & 1 & 5 & 3.98 & .823 \\
\hline Building a good work environment is one of strategy's milestones & 277 & 1 & 5 & 4.11 & 1.021 \\
\hline There are work environments that are aggressive to leadership & 277 & 1 & 5 & 3.98 & .907 \\
\hline The management should work on building environments suitable for strategic leadership & 277 & 1 & 5 & 4.15 & 1.009 \\
\hline \multicolumn{6}{|l|}{$\begin{array}{ll} & \\
& \end{array}$} \\
\hline A leader has to be strategic in their thinking in order to be considered strategic leaders & 277 & 1 & 5 & 3.82 & .955 \\
\hline A strategic leader should be open to change & 277 & 1 & 5 & 3.95 & 1.000 \\
\hline A strategic leader should enjoy a strategic thinking & 277 & 1 & 5 & 3.95 & 1.086 \\
\hline A strategic leader should be focused and precise in their approach & 277 & 1 & 5 & 3.94 & 1.108 \\
\hline Being a strategic leader is a part of being courageous and prudent & 277 & 1 & 5 & 4.02 & 1.108 \\
\hline \multicolumn{6}{|l|}{ Leadership Style } \\
\hline Leadership approach defines if it is strategic or not & 277 & 1 & 5 & 3.78 & 1.090 \\
\hline A strategic leader is mostly a transformational leader & 277 & 1 & 5 & 3.69 & .870 \\
\hline Autocratic leader can't be strategic & 277 & 1 & 5 & 3.96 & .939 \\
\hline The style of leadership is the main way to build a strategic leadership approach & 277 & 1 & 5 & 3.90 & .982 \\
\hline There is always different leadership styles for strategic leadership & 277 & 1 & 5 & 3.79 & .936 \\
\hline \multicolumn{6}{|l|}{ Strategic Leaders' Performance } \\
\hline $\begin{array}{l}\text { A strategic leader is a person who has clear vision, task, objective and policy to lead or- } \\
\text { ganization towards performance }\end{array}$ & 277 & 2 & 5 & 3.86 & .831 \\
\hline Strategic leaders encourage their employees to increase their performance & 277 & 1 & 5 & 4.01 & .957 \\
\hline Strategic leaders have the best performance in the organization & 277 & 1 & 5 & 3.93 & 1.028 \\
\hline Strategic leaders pave the way for their employees to present the best performance & 277 & 1 & 5 & 4.03 & 1.111 \\
\hline Performance-based management is how strategic leaders deal with employees & 277 & 1 & 5 & 3.95 & 1.059 \\
\hline \multicolumn{6}{|l|}{ Ethical Practices } \\
\hline an ethical system can be designed to support ethical conduct & 277 & 1 & 5 & 3.78 & .948 \\
\hline Ethical leadership is a part of ethical conduct & 277 & 1 & 5 & 4.03 & .918 \\
\hline Leadership style can influence ethical digestion in an organization & 277 & 1 & 5 & 3.91 & .916 \\
\hline $\begin{array}{l}\text { Strategic leadership can set standards, model appropriate behavior, and hold everyone } \\
\text { accountable for their decisions and behavior }\end{array}$ & 277 & 1 & 5 & 4.06 & 1.051 \\
\hline Strategic leadership supports the existence of ethics in an organization & 277 & 1 & 5 & 3.99 & .891 \\
\hline A strategic leader is an ethical leader for sure & 277 & 1 & 5 & 3.90 & .907 \\
\hline Valid N (listwise) & 277 & & & & \\
\hline
\end{tabular}

Table 2

Variable analysis

\begin{tabular}{|c|c|c|c|c|c|}
\hline & $\mathrm{N}$ & Minimum & Maximum & Mean & Std. Deviation \\
\hline Environment & 277 & 1.60 & 5.00 & 4.0968 & .74903 \\
\hline Traits & 277 & 1.40 & 5.00 & 3.9329 & .85565 \\
\hline Style & 277 & 1.20 & 5.00 & 3.8238 & 69939 \\
\hline Performance & 277 & 1.40 & 5.00 & 3.9560 & .72448 \\
\hline Ethical & 277 & 1.67 & 5.00 & 3.9422 & .67198 \\
\hline
\end{tabular}

\section{Hypotheses Testing}

\subsection{Main Hypothesis: The relationship between strategic leadership and ethical practices}

The first hypothesis of this survey investigates the relationship between strategic leadership and ethical practices. Table 3 presents the results of the regression analysis. The results show that all independent variables are meaningful when the level of significance is five percent. F-value is equal to 82.431(0.000) which means the relationship is linear. Finally, Adjusted RSquare is equal to 0.541 , which indicates that the independent variables present approximately $54 \%$ of the changes on dependent variable.

Table 3

The summary of the results of regression analysis

\begin{tabular}{|c|c|c|c|c|c|c|}
\hline \multirow{2}{*}{\multicolumn{2}{|c|}{ Model }} & \multicolumn{2}{|c|}{ Unstandardized Coefficients } & \multirow{2}{*}{$\begin{array}{c}\text { Standardized Coefficients } \\
\text { Beta }\end{array}$} & \multirow[t]{2}{*}{$\mathrm{t}$} & \multirow[t]{2}{*}{ Sig. } \\
\hline & & $\mathrm{B}$ & Std. Error & & & \\
\hline \multirow[t]{5}{*}{1} & (Constant) & .834 & .178 & & 4.679 & .000 \\
\hline & Work Environment & .154 & .053 & .172 & 2.914 & .004 \\
\hline & Leaders' Traits & .096 & .047 & .122 & 2.022 & .044 \\
\hline & Leadership Style & .154 & .055 & .160 & 2.818 & .005 \\
\hline & Strategic leadership Performance & .382 & .055 & .412 & 7.010 & .000 \\
\hline
\end{tabular}

Adjusted R-Square $=0.541 \mathrm{~F}$-value $=82.431(0.000)$

We now examine the effect of each independent variable on ethical practices. 
Table 4 shows the results of simple regression analysis. According to the results of Table 4, environmental issues has positive and meaningful impact on ethical practices. According to Adjusted R-Square, the regression analysis explains that the independent variable could describe approximately $33 \%$ of the changes on dependent variable.

\section{Table 4}

The summary of the regression analysis between environment (dependent variable) and ethical practices

\begin{tabular}{|c|c|c|c|c|c|}
\hline \multirow[t]{2}{*}{ Model } & \multicolumn{2}{|c|}{ Unstandardized Coefficients } & \multirow{2}{*}{$\begin{array}{c}\text { Standardized Coefficients } \\
\text { Beta }\end{array}$} & \multirow[t]{2}{*}{$\mathrm{t}$} & \multirow[t]{2}{*}{ Sig. } \\
\hline & $\mathrm{B}$ & Std. Error & & & \\
\hline (Constant) & 1.795 & .183 & & 9.818 & .000 \\
\hline Environment & .524 & .044 & .584 & 11.935 & .000 \\
\hline
\end{tabular}

Adjusted R-Square $=0.339$ F-value $=142.434(0.000)$

The effect of leader's traits on ethical practices

Table 5 presents the results of simple regression analysis where leader's traits has positive and meaningful impact on ethical practices. The regression analysis describes that the independent variable could describe approximately $32 \%$ of the changes on dependent variable.

Table 5

The summary of the regression analysis between leaders' traits (dependent variable) and ethical practices

\begin{tabular}{|c|c|c|c|c|c|}
\hline \multirow[t]{2}{*}{ Model } & \multicolumn{2}{|c|}{ Unstandardized Coefficients } & \multirow{2}{*}{$\frac{\text { Standardized Coefficients }}{\text { Beta }}$} & \multirow[t]{2}{*}{$\mathrm{t}$} & \multirow[t]{2}{*}{ Sig. } \\
\hline & $\mathrm{B}$ & Std. Error & & & \\
\hline (Constant) & 2.178 & .156 & & 13.921 & .000 \\
\hline Leader's trait & .449 & .039 & .571 & 11.542 & .000 \\
\hline
\end{tabular}

Adjusted R-Square $=0.324$ F-value $=133.227(0.000)$

The effect of leader's style on ethical practices

Table 6 describes the results of simple regression analysis where leader's style has positive and meaningful impact on ethical practices. The regression analysis presents that the independent variable could describe approximately $32 \%$ of the changes on dependent variable.

Table 6

The summary of the regression analysis between leader's style (dependent variable) and ethical practices

\begin{tabular}{|c|c|c|c|c|c|}
\hline \multirow[t]{2}{*}{ Model } & \multicolumn{2}{|c|}{ Unstandardized Coefficients } & \multirow{2}{*}{$\begin{array}{c}\text { Standardized Coefficients } \\
\text { Beta }\end{array}$} & \multirow[t]{2}{*}{$\mathrm{t}$} & \multirow[t]{2}{*}{ Sig. } \\
\hline & $\mathrm{B}$ & Std. Error & & & \\
\hline (Constant) & 1.784 & .182 & & 9.787 & .000 \\
\hline Leader's style & .565 & .047 & .588 & 12.041 & .000 \\
\hline
\end{tabular}

Adjusted R-Square $=0.343$ F-value $=144.993(0.000)$

The effect of performance on ethical practices

Table 7 describes the results of simple regression analysis where leader's performance maintains positive and meaningful impact on ethical practices. The regression analysis presents that the independent variable (leader's performance) could describe approximately $48 \%$ of the changes on dependent variable.

Table 7

The summary of the regression analysis between leader's performance (dependent variable) and ethical practices

\begin{tabular}{|c|c|c|c|c|c|}
\hline \multirow[t]{2}{*}{ Model } & \multicolumn{2}{|c|}{ Unstandardized Coefficients } & \multirow{2}{*}{$\frac{\text { Standardized Coefficients }}{\text { Beta }}$} & \multirow[t]{2}{*}{$\mathrm{t}$} & \multirow[t]{2}{*}{ Sig. } \\
\hline & $\mathrm{B}$ & Std. Error & & & \\
\hline (Constant) & 1.415 & .163 & & 8.675 & .000 \\
\hline Leader's performance & .639 & .041 & .689 & 15.759 & .000 \\
\hline
\end{tabular}

Adjusted R-Square $=0.475$ F-value $=248.360(0.000)$

\section{Discussion}

Looking at results above, it appeared that main hypothesis of study was accepted and there is an actual influence of strategic leadership on ethical practices in an organization, which gives an indication that following a strategic leadership approach is helpful in increasing the efficiency of ethical practices among individuals. Results of study showed that strategic leaders also play a distinctive role in the spirit of organizational citizenship and social responsibility through many practices, including fraternal and kind dealing with others, provide a safe workplace, take deterrent measures to protect the environment, play a pivotal role in community issues and issues, reducing the size of unemployment and employing the disabled in a manner commensurate with the nature of work and provide material and moral support for charitable projects. 
The same idea appeared by Sabir et al. (2012) who argued that among the influences of leadership developed performance is the development of ethical stands and perspective of its employees. Also, Sendjaya and Pekerti (2010) noted to the fact that leadership styles play a role in influencing the ethical viewpoints of individuals, however, a strategic leadership that proved its high performance might be stronger in attracting its individuals and employees towards adopting more ethical perspective when it comes to performance and decision making process. On the other hand, work environment and leadership style appeared to the second in influence rank on ethical practices in an organization with a B value of .154 for both. To clear this idea, work environment - not only materialistic environment but also the abstract environment- play a role in increasing individuals' attraction to practice their job ethically and according to ethics in business and leadership. Brown and Mitchell (2010) stated that an ethical environment is the best way to increase ethics in an organization while Çelik et al. (2015) argued that an environment that is based on ethics and sun by ethical leadership is mostly an environment that encourages ethical practices among its employees. The same goes for leadership styles which also appeared to be influential on ethical practices of employees referring to the fact that there is no specific style for ethical leadership but there is specific traits for a leadership to be seen as ethical including honesty, respect, integrity and truthfulness; this idea was agreed on by Kang (2019).

\section{Conclusion and Recommendations}

There are basic needs for organizations no matter what its field of interest was which is an effective leadership. It was revealed through the study that an effective leadership is a synonym to what is called a strategic leadership which is a smart approach armed with awareness and developed thinking and that is able to support an organization through its path to achieve the previously set mission and vision. Strategic leadership is more able to rationalize individuals' behavior, mobilize their energies and abilities, coordinate their efforts, organize their affairs and direct them towards the right goals and objectives. Among the characteristics of strategic leadership that makes it supportive to business ethics is the fact that it can be a source of innovations and creativeness through gathering between cognitive abilities of individuals and the creative leadership among strategic leaders. In addition to that, strategic leadership possess a future perspective that plays an important role in the process of strategies execution through multiple practices and activates which leads to strategic balance and intersected needs within an organization. Generally speaking, strategic leaders can consolidate ethical practices in their organizations by making themselves a role model and urging others to make ethical decisions and promoting ethical training programs, also, the support of senior management for ethical behavior at all organizational levels is important and effective in motivating individuals to work ethically in the organization.

According to discussion and conclusion, current study recommended the following:

- Change management is the first step towards employing strategic leadership in an organization which may lead to ethical practices.

- Organizations within pharmaceutical industry should pay extra attention to aspects that are related to increasing employees' awareness towards ethics in leadership and business.

- Convincing to adopt and ethical stream of thinking should be based on results and overwhelming evidence not on theories.

\section{References}

Auvinen, T. P., Lämsä, A. M., Sintonen, T., \& Takala, T. (2013). Leadership manipulation and ethics in storytelling. Journal of Business Ethics, 116(2), 415-431.

Avolio, B. J. (2007). Promoting more integrative strategies for leadership theory-building. American psychologist, $62(1), 25$.

Bouhali, R., Mekdad, Y., Lebsir, H., \&Ferkha, L. (2015). Leader roles for innovation: Strategic thinking and planning. Procedia-Social and Behavioral Sciences, 181, 72-78.

Brown, M. E., \& Mitchell, M. S. (2010). Ethical and unethical leadership: Exploring new avenues for future research. Business Ethics Quarterly, 20(4), 583-616.

Carter, S. M., \& Greer, C. R. (2013). Strategic leadership: Values, styles, and organizational performance. Journal of Leadership \& Organizational Studies, 20(4), 375-393.

Çelik, S., Dedeoğlu, B. B., \&Inanir, A. (2015). Relationship between ethical leadership, organizational commitment and job satisfaction at hotel organizations. EgeAkademikBakışDergisi, 15(1), 53-64.

Chanpoom, N., \& Intrawong, W. (2019). The Influence of Strategic Leadership and Organizational Climate on Organizational Commitment of Savings Cooperative Employees, Thailand.

Davies, B. J., \& Davies, B. (2004). Strategic leadership. School leadership \& management, 24(1), 29-38.

Dyson, K. (2014). Chancellor kohl as strategic leader: The case of economic and Monetary Union. In The Kohl Chancellorship (pp. 37-63). Routledge.

Ferrell, O. C., \&Fraedrich, J. (2015). Business ethics: Ethical decision making \& cases. Nelson Education.

Gallagher, A., \&Tschudin, V. (2010). Educating for ethical leadership. Nurse education today, 30(3), 224-227.

Graham, K. A., Ziegert, J. C., \&Capitano, J. (2015). The effect of leadership style, framing, and promotion regulatory focus on unethical pro-organizational behavior. Journal of Business Ethics, 126(3), 423-436. 
Grant, A. M. (2012). Leading with meaning: Beneficiary contact, prosocial impact, and the performance effects of transformational leadership. Academy of Management Journal, 55(2), 458-476.

Jansen, J. J., Vera, D., \&Crossan, M. (2009). Strategic leadership for exploration and exploitation: The moderating role of environmental dynamism. The Leadership Quarterly, 20(1), 5-18.

Kang, S. W. (2019). Sustainable Influence of Ethical Leadership on Work Performance: Empirical Study of Multinational Enterprise in South Korea. Sustainability, 11(11), 3101.

Kanungo, R. N. (2001). Ethical values of transactional and transformational leaders. Canadian Journal of Administrative Sciences/Revue Canadienne des Sciences de l'Administration, 18(4), 257-265.

McCleskey, J. A. (2014). Situational, transformational, and transactional leadership and leadership development. Journal of Business Studies Quarterly, 5(4), 117.

Mihelic, K. K., Lipicnik, B., \&Tekavcic, M. (2010). Ethical leadership. International Journal of Management \& Information Systems (IJMIS), 14(5).

Myers, R. B., \& Pierce, A. C. (2009). On strategic leadership. JFQ: Joint Force Quarterly, 54, 12-13.

Palazzo, G., \& Richter, U. (2005). CSR business as usual? The case of the tobacco industry. Journal of Business Ethics, 61(4), 387-401.

Petryna, A., Lakoff, A., \&Kleinman, A. (Eds.). (2006). Global pharmaceuticals: Ethics, markets, practices. Duke University Press.

Phipps, K. A. (2012). Spirituality and strategic leadership: The influence of spiritual beliefs on strategic decision making. Journal of business ethics, 106(2), 177-189.

Phipps, K. A., \&Burbach, M. E. (2010). Strategic leadership in the nonprofit sector: Opportunities for research. Journal of Behavioral and Applied Management, 11(2), 137.

Rhaima, S, H. (2012). The role of strategic leadership skills in the proactive to the work Stress: An analytical study of the opinions sample of military leaders. Al-Anbar University Journal, 4(9)

Rogers, W. A., Mansfield, P. R., Braunack-Mayer, A. J., \&Jureidini, J. N. (2004). The ethics of pharmaceutical industry relationships with medical students. Medical Journal of Australia, 180(8), 411-414.

Rutherford, M. A., Parks, L., Cavazos, D. E., \& White, C. D. (2012). Business ethics as a required course: Investigating the factors impacting the decision to require ethics in the undergraduate business core curriculum. Academy of Management Learning \& Education, 11(2), 174-186.

Sabir, M. S., Iqbal, J. J., Rehman, K. U., Shah, K. A., \&Yameen, M. (2012). Impact of corporate ethical vaulues on ethical leadership and employee performance. International Journal of Business and Social Science, 3(2).

Santoro, M. A., \&Gorrie, T. M. (2005). Ethics and the pharmaceutical industry. Cambridge University Press.

Sendjaya, S., \&Pekerti, A. (2010). Servant leadership as antecedent of trust in organizations. Leadership \& Organization Development Journal, 31(7), 643-663.

Takeuchi, R., Chen, G., \&Lepak, D. P. (2009). Through The Looking Glass of a Social System: Cross-Level Effects Of HighPerformance Work Systems On Employees'Attitudes. Personnel Psychology, 62(1), 1-29.

Trevino, L. K., \& Brown, M. E. (2004). Managing to be ethical: Debunking five business ethics myths. Academy of Management Perspectives, $18(2), 69-81$.

Tutar, H. Altinoz, M and Cakiroglu, D. (2011). Is ethical leadership and strategic leadership a dilemma? A descriptive survey. $7^{\text {th }}$ International Strategic Management Conference.

Van Schalkwyk, S., Du Toit, D. H., Bothma, A. S., \&Rothmann, S. (2010). Job insecurity, leadership empowerment behaviour, employee engagement and intention to leave in a petrochemical laboratory. SA Journal of Human Resource Management, 8(1), 7 .

Wu, L. Z., Kwan, H. K., Yim, F. H. K., Chiu, R. K., \& He, X. (2015). CEO ethical leadership and corporate social responsibility: A moderated mediation model. Journal of Business Ethics, 130(4), 819-831.

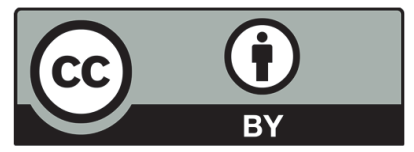

(C) 2020 by the authors; licensee Growing Science, Canada. This is an open access article distributed under the terms and conditions of the Creative Commons Attribution (CC-BY) license (http://creativecommons.org/licenses/by/4.0/). 